\title{
Perceived Usefulness, Attitude, and E-Learning Satisfaction of Graduate Students PGRI University of Palembang
}

\author{
Riska Hasanah $^{1 *}$, Baginda Simaibang ${ }^{1}$, Artanti Puspita Sari ${ }^{1}$ \\ ${ }^{1}$ Universitas PGRI Palembang, Indonesia \\ *Corresponding author. Email: ms.riskahasanah@gmail.com
}

\begin{abstract}
The aim of this research is to examine the online learning process used by students in the Graduate Program at PGRI University of Palembang. This research aims to assess the perceived usefulness of e-learning, students' attitudes, and students' satisfaction with e-learning. In this analysis, mixed approaches were used, with the quantitative approach using a collection of survey questionnaires. In the meantime, the quantitative approach employed an interrogation. The findings revealed that the perceived utility of e-learning and student satisfaction with e-learning were both strong. Though students' attitudes toward e-learning are mild. Furthermore, it provides input towards the implementation of online-based learning, especially in the "New Normal" era.
\end{abstract}

Keywords: Perceived Usefulness, Attitude, Satisfaction, E-Learning

\section{INTRODUCTION}

Dr. Tedros Adhanom Ghebreyesus, Director General of the World Health Organization (WHO), officially reported the Corona virus (COVID-19) as a pandemic on March 11, 2020. The global spread of the COVID-19 pandemic has deeply altered almost every aspect of life, including education, and Indonesia has not been immune to these changes. Because of the difficulty in preventing the outbreak from spreading further, world leaders have established extremely stringent rules to break the chain of COVID-19 spread. Some of the World Health Organization's (2019) recommended guidelines, such as social and physical distancing, have provided challenging choices for each country to adopt. Due to the rising number of people infected with COVID-19, Indonesia introduced "large-scale social restrictions" in March 2020. This were accompanied by additional laws such as working from home for staff, praying from home, and home schooling for students from early childhood education to higher education.

Changes in the educational environment necessitate the implementation of distance education or online learning, e-learning, distance education, correspondence education, external research, flexible learning, and wide-open online courses (MOOCs). Online education represents a major shift in how people learn and in turn, how learners are taught [1]. In the United States, the same requirements and rules apply. According to the Centers for Disease Control and Prevention (2020), elearning plans, including remote and distance learning options, have been introduced as feasible and necessary to ensure student education continuity during the COVID-19 pandemic. A report from The World Bank (2020) stated that several countries had implemented different learning systems as physical schools were closed due to COVID-19.

In implementing online learning, PGRI University of Palembang facilitates distance learning through elearning services. Basically, long before the pandemic occurred, PGRI University of Palembang as a digital university had run a blended-learning system that is a combination of face-to-face learning and online learning. Through the e-learning platform that can be accessed on a web page with address https://elearning.univpgri-palembang.ac.id students can access course material, conduct discussions in forums, and also send files for lecture purposes. This service was introduced in 2018 but until now there has never been an evaluation of its use.

Based on the interview with several Graduate students of PGRI University of Palembang, the result showed that some of them are not actively participating in online learning for varied reasons such as limited access of internet. Some students were living in their hometown that may not have access to internet or limited internet access.

Another reason was limited time. Some students were working full time therefore they could not access e-learning service in workdays. Unfortunately, they 
found several courses held not on schedule. These interview results showed that e-learning services have not been maximally utilized by students.

TAM has been successfully identified students' decision to use a learning system. The main objective of this model is to explain the individual's behavior towards the adoption of technology [2]. TAM has central variables; perceived ease of use and perceived usefulness which directly influence attitude toward technology use [3]. However, Davis [3] reinforces his statement that perceived usefulness was $50 \%$ stronger than perceived ease of use to influence users' attitudes towards using a technology. The inclusion of various technological tools plays a significant role in stimulating the online education environment and encouraging critical thinking in collaborative interaction [4]. Therefore, in this study the writer will only explore one of the constructs of Technology Acceptance Model (TAM), namely the perceived usefulness construct and its relation to the attitude, and satisfaction of graduate students of PGRI University of Palembang on e-learning services during online learning process.

\section{METHODS}

In carrying out this research, researcher used mixed methods research to obtain comprehensive, valid, reliable and objective data. The researcher used readymade questionnaires created by Arulnachalam [5]. The data was analyzed with the Statistical Kit for Social Science (SPSS V.20). Meanwhile, qualitative data was gathered through interviews.

\section{RESULTS AND DISCUSSION}

\section{1) Questionnaire}

The questionnaire is filled out by 154 graduate students of PGRI University of Palembang using Google Form.

The results of students' perceived usefulness responses on e-learning indicate that students' perceived usefulness is high. The majority of respondents' responses suggest that the majority of respondents believe that e-learning is useful in promoting their learning operation. Pham et al., [6] established three dimensions of e-learning service quality: e-learning system quality, e-learning teacher and course content quality, and e-learning administrative and support service quality.

Meanwhile, the results of the students' responses to the questionnaire regarding their attitudes in online learning shows that student attitudes are at a moderate level. On average, respondents' responses are at level neutral. This response is related to their impression after learning using e-learning system. E-learning refers to the use of electronic media by lecturers to teach and learn at a distance [7]. E-learning has simplified learning by introducing several new approaches and tools [8]. This shows that the majority of respondents do not experience positive or negative impressions in online learning activities.

Furthermore, the results of student satisfaction responses to e-learning show that student satisfaction with the e-learning system at the PGRI University of Palembang is high. This shows that on average the respondents are satisfied with the activities of the elearning.

\section{2) Interview}

To support the data from questionnaire, the researcher conducted interview with research participants. Based on the interview, it is found that some of respondents acknowledged that learning from home was the best option during this COVID-19 pandemic. This is related to the government policy which encourages physical or social distancing in order to protect people from exposure to the corona virus and prevent the virus from spreading further.

Based on the finding from interview, it could be said that students have positive responses on perceived usefulness. It shows that students see e-learning as a valuable tool to help them with their studies.

When asking about their attitude towards online learning, they responded that they have neutral impressions after using e-learning in learning process. This is due to the missing aspects of online learning system. Some respondents tend to learn better when face-to-face learning because of the 'real' interaction between students and lecturers in conventional learning. Therefore, they consider they are not kind of person who learns well by using online learning system but they found online learning is very useful especially during pandemic.

And based on the interview with the respondents regarding their satisfaction on online learning, it can be concluded that they are satisfied with the e-learning system, but they prefer to have conventional learning when in a normal situation. Students who are satisfied with their university experience will give their all to their learning activities, resulting in higher academic achievement [9].

From the findings of perceived usefulness questionnaire and interview, it can be concluded that on average students have a high perceived usefulness of elearning systems. This is in accordance with the opinion of Davis [3] Perceived usefulness reflects a person's belief that the use of information technology will provide benefits for its users.

\section{a. Students' Attitude toward E-Learning}

From the findings of students' attitude questionnaire and interview, it can be concluded that respondents shows neither positive or negative attitudes towards elearning systems. Students do not show positive or 
negative attitude after learning using e-learning. However, on average, students agree that online learning is a good tool for discussion with peers. The most dominant attitude indicator of students is the attitude of enjoying to share knowledge with peers which can be facilitated by the online system. This shows that e-learning helps students share more ideas with other students in an online learning system rather than conventional learning.

\section{b. Students' Satisfaction towards E-learning}

From the findings of students' attitude questionnaire and interview, it can be concluded that on average students have high satisfaction with the online learning system. Most of the students agree that the online system provides convenience, always available at all times, well-ordered, has a good design, provides updated and useful content, allows control of teaching progress, and can record progress and performance in the process learning.

Perceived usefulness affects satisfaction using an online learning system [4]. In addition, attitudes towards e-learning are a contributing factor to the use of elearning [4]. Thus, theoretically it can be said that the perceived usefulness and attitude affect the satisfaction of using online systems. In this study, it is possible that there is an influence of perceived usefulness and attitude variables on student satisfaction in the use of online learning systems. However, this still needs to be proven further through statistical tests.

Several studies have examined the relationship between online learning satisfaction and academic achievement among college students [10]; [11]; [12];[13] at universities that have long used online learning [14];[15];[16] This study largely builds on and improves on previous research findings, although it was conducted at universities that were new to utilizing an online learning method as a result of the COVID 19 event.

\section{CONCLUSION}

From the results of the discussion that has been carried out, it can be concluded as follows: 1) on average students have high satisfaction with the online learning system but they prefer to have conventional learning when in a normal situation; 2) have a high perceived usefulness of e-learning systems, and 3) most of the students agree that the online system provides convenience, always available at all times, well-ordered, has a good design, provides updated and useful content, allows control of teaching progress, and can record progress and performance in the process learning.

\section{ACKNOWLEDGMENTS}

Our deepest gratitude goes to Teachers in SD Negeri Keluang District, Chancellor of Palembang PGRI University, Director of the Postgraduate Program of
PGRI Palembang University and the Education Management Study Program of PGRI Palembang University, who have supported us in doing this extraordinary thing. This project is funded independently. We also want to thank our Education Management friends who helped us a lot in a short time frame to complete this project.

\section{REFERENCES}

[1] Cole, M. T., Shelley, D. J., \& Swartz, L. B. (2014). Online Instruction, E-Learning, and Student Satisfaction: A 3 Year Study. Creative Commons Attribution 4.0 International License. Vol 15, No 6.

[2] Chang, C. T., Hajiyev, J., \& Su, C. R. (2017). Examining the students' behavioral intention to use e-learning in Azerbaijan? The General Extended Technology Acceptance Model for E-learning approach. Computers \& Education, 111(17), 128143.

[3] Davis, F. D. (1989). Perceived usefullness, perceived ease of use, and user acceptance of information technology. MIS Quarterly. 13, 3.

[4] Almusharraf, N. M., \& Khahro, S. H. (2020). Students' Satisfaction with Online Learning Experiences During the COVID-19 Pandemic. iJET-Vol. 15, No. 21.

[5] Arulnachalam, T. (2019). An investigation on the role of perceived ease of use, perceived use, and self-efficacy in determining continuous usage intention towards an e-learning system. The Online Journal of Distance Education and e-Learning, October 2019, 7(4), 268-276.

[6] Pham, L., Limbu, Y. B., Bui, T. K., Nguyen, H. T., \& Pham, H. T. (2019). Does e-learning service quality influence e-learning student satisfaction and loyalty? Evidence from Vietnam. International Journal of Educational Technology in Higher Education, 16(1). https://doi.org/10.1186/s41239019-0136-3

[7] Teo, T., 2011. Modeling the determinants of preservice teachers' perceived usefulness of elearning. Campus-Wide Information Systems, 28(2): 124-140.

[8] Anarinejad, A., (2010). Designing a conceptual framework for evaluation of e-learning programs in higher education institutes. Journal of ScientificResearch of Education Technology, 4(4): 3-11.

[9] Satuti, J. R., Sunaryanto., \& Nuris, D. M. (2020). Does Student Satisfaction Mediate the Correlation between E-Learning Service Quality, Academic Engagement and Academic Achievement? Journal of Accounting and Business Education, 5 (1).

[10] Chen., et al. (2020). Analysis of User Satisfaction with Online Education Platforms in China during 
the COVID-19 Pandemic. Healthcare, 8(200), 126.

[11] Karwati, E. (2014). Pengaruh Pembelajaran elektronik (e-learning) terhadap mutu belajar mahasiswa [The effect of electronic learning (elearning) on the quality of student learning]. Jurnal Penelitian Komunikasi, 17(1), 41-54.

[12] Loton, D., Parker, P., Stein, C., \& Gauci, S. (2020). Remote learning during COVID-19: Student satisfaction and performance. https://doi.org/10.35542/osf.io/n2ybd

[13] Napituli, R. A. (2020). Dampak pandemi Covid19 terhadap kepuasan pembelajaran jarak jauh [The impact of the Covid19 pandemic on distance learning satisfaction]. Jurnal Inovasi Teknologi Pendidikan, 7(1), 23-33.

[14] Ebner, C., \& Gegenfurtner, A. (2019). Learning and Satisfaction in Webinar, Online, and Face-toFace Instruction: A MetaAnalysis. Frontiers in Education, 4(92), 1-11. https://doi.org/10.3389/feduc.2019.00092

[15] Prasetya, T. A., \& Harjanto, C. T. (2020). Pengaruh Mutu Pembelajaran Online dan Tingkat Kepuasan Mahasiswa Terhadap Hasil Belajar saat PAndemi COVID 19 [The Effect of Online Learning Quality and Student Satisfaction Levels on Learning Outcomes during the COVID-19 epidemic]. Jurnal Pendidikan Teknologi dan Kejuruan, 17(2), 188-197. http://dx.doi.org/10.23887/jptkundiksha.v17i2.252 $\underline{86}$

[16] Sockalingam, N. (2012). The Relation between Student Satisfaction and Student Performance in Blended Learning Curricula. International Journal of Learning. 18(12), 121-134. 